\title{
Kaolin as a Source of Silica and Alumina For Synthesis of Zeolite $\mathrm{Y}$ and Amorphous Silica Alumina
}

\author{
Endang Sri Rahayu ${ }^{1, *}$, Gatot Subiyanto ${ }^{1}$, Arief Imanuddin ${ }^{1}$, Wiranto ${ }^{1}$, Sabrina Nadina $^{1}$, Rista Ristiani $^{1}$, \\ Suhermina ${ }^{1}$, and Endang Yuniarti ${ }^{1}$ \\ ${ }^{1}$ Chemical Engineering Department, Bandung State Polytechnic, Indonesia
}

\begin{abstract}
Kaolin is the clay mineral which containing silica $\left(\mathrm{SiO}_{2}\right)$ and alumina $\left(\mathrm{Al}_{2} \mathrm{O}_{3}\right)$ in a high percentage, that can be used as a nutrient in the synthesis of zeolites and amorphous silica alumina (ASA). The objective of this research is to convert the Belitung kaolin into silica and alumina as nutrients for the synthesis of zeolites and amorphous silica alumina, which are required in the preparation of the catalysts. Silica and alumina contained in the kaolin were separated by leaching the active kaolin called as metakaolin, using HCL solution, giving a solid phase rich silica and a liquid phase rich alumina. The solid phase rich silica was synthesized to zeolite $Y$ by adding seed of the $Y$ Lynde type, through the hydrothermal process with an alkaline condition. While, the liquid phase rich alumina was converted into an amorphous silica alumina through a co precipitation method. Characterization of zeolite and ASA were done using XRD, surface area and pore analyzer and SEM. The higher of alumina in liquid phase as a result of the rising molar of HCL in the leaching process was observed, but it didn't work for its rising time. Products of ASA and zeolite $Y$ were obtained by using liquid phase rich alumina and solid phase rich silica, respectively, which resulted through leaching metakaolin in $2.5 \mathrm{M} \mathrm{HCl}$ at temperature of $100^{\circ} \mathrm{C}$ for 2 hours.
\end{abstract}

\section{Introduction}

Kaolin is the clay mineral which containing silica $\left(\mathrm{SiO}_{2}\right)$ and alumina $\left(\mathrm{Al}_{2} \mathrm{O}_{3}\right)$ which are inert and inactive, which can be activated through the process of calcination. When the calcination of the kaolin is taken place, the regular crystal structure of kaolinite with inactive $\mathrm{Si}-\mathrm{O}$ and $\mathrm{Al}-\mathrm{O}$ bonds is converted to metakaolin with an irregular amorphous alumino silicate structure, with active $\mathrm{Si}-\mathrm{O}$ and $\mathrm{Al}-\mathrm{O}$ bonds.

Zeolite and Amorphous Silica Alumina (ASA) are built by atoms of $\mathrm{Al}, \mathrm{Si}$ and $\mathrm{O}$, therefore these materials can be synthesized with raw materials containing silica and alumina compounds. Accordingly, kaolin is a cheap natural material that containing silica and alumina in a high percentage. However, kaolin is inert and inactive, so it requires activation to form the active kaolin, that can be done through the process of calcination. Metakaolin is a relatively inexpensive active kaolin, in which the silica and alumina content can be separated through leaching by acid, that will produce silica-rich solids and alumina-rich liquids. The Silica-rich solids with a certain silica/alumina molar ratio are required in the synthesis of zeolites [1]. Both of the process conditions of calcinating kaolin and leaching metakaolin will affect the results of the separation of silica and alumina. When metakaolin is leached, the $\mathrm{Al}$ sheet would be dissolved, that causes the different environment of the $\mathrm{Si}$ atoms to form microporous silica [2].

There are few papers reporting on leaching metakaolin for using silica-rich solid as a nutrient in the synthesis of zeolites. Process of leaching metakaolin using $\mathrm{H}_{2} \mathrm{SO}_{4} 5.2 \mathrm{~N}$ at temperature of $90^{\circ} \mathrm{C}$ within 2 hours, resulting in silica-rich solids having a surface area of $400 \mathrm{~m}^{2} / \mathrm{g}$ and a pore size of $0.7 \mathrm{~nm}$, as a source of silica for the synthesis of zeolite Y [3]. Ajayi (2010) reported that leaching metakaolin using $\mathrm{H}_{2} \mathrm{SO}_{4}>50 \%-\mathrm{W}$ in the starting material will result in rasio of Si/Al > $5 \mathrm{w} / \mathrm{w}$ [4]. Mamani (2014) has successfully separated silica and alumina in metakaolin using $\mathrm{HCl} 3 \mathrm{M}$ at temperature of $115^{\circ} \mathrm{C}$ during 2.5 hours, which produces a silica-rich solid with molar ratio of silica/alumina between $20-40 \mathrm{~mol} / \mathrm{mol}$, that is suitable for nutrient of the synthesize ZSM5 [5]. Leaching of metakaolin by using $\mathrm{H}_{2} \mathrm{SO}_{4}$ has also been done by Adeoye (2017), which produces silica-rich solids with a molar ratio between $3-8 \mathrm{~mol} / \mathrm{mol}$ [6] .

The main purpose of this paper is to improve efficiency of the synthesis process of zeolite $\mathrm{Y}$ from kaolin that has been done previously [7-8], by substituting the supply of porous silica through the process of leaching metakaolin rather than calcinating of kaolin at high exothermic temperature. Furthermore, alumina-rich liquids were be used as nutrients for synthesis of ASA.

\section{Experimental}

\subsection{Materials and methods}

The material for the synthesis of Zeolite $\mathrm{Y}$ comprises of the silica-rich solids resulting in leaching metakaolin, Sodium hydroxide, demineral water and crystal seed of Lynde Type $\mathrm{Y}$ wherein contain Merck sodium silicate, Aldrich sodium aluminate, technical sodium hydroxide and demineral water. The material for ASA synthesis comprises of mother liquor resulted of leaching metakaolin, and ammonia or sodium hydroxide.

\subsubsection{Metakaolin}

Corresponding author: endang.srirahayu@polban.ac.id 
Metakaolin is an active kaolin of Belitung kaolin which is required to provide $\mathrm{Si}-\mathrm{O}$ and $\mathrm{Al}-\mathrm{O}$ actives, which are the source of silica and alumina for the synthesis of zeolite Y and ASA. Metakoline was prepared by calcinating of kaolin in Nabertherm $\mathrm{GmbH}$ furnace at $700^{\circ} \mathrm{C}$ for 2 hours, where the kaolin dehydroxylation process takes place to form metakaolin completely, through endothermic reaction.

This temperature is determined by kaolin thermal characterization, using a DSC / TGA.

\subsubsection{Silica and Alumina}

Preparation of the active silica and alumina was done by leaching process using $\mathrm{HCl}$ between 2-3 $\mathrm{M}$ at temperature $100^{\circ} \mathrm{C}$, with the weight ratio of $\mathrm{HCl} /$ metakaolin solution was 10: $1 \mathrm{w} / \mathrm{w}$, for 2-4 hours. The leaching product of metakaolin is filtered to obtain silica-rich solids, and alumina-rich solutions.

The silica-rich solids are rinsed to neutral $\mathrm{pH}$, dried in an oven at temperature of $110^{\circ} \mathrm{C}$ for 8 hours, and characterized by AAS. The alumina-rich solution was analyzed by gravimetric method. The condition of the leaching process is adjusted to obtain a silica-rich solids having silica / alumina molar ratio in between 7$10 \mathrm{~mol} / \mathrm{mol}$.

\subsection{Synthesis Zeolite $\mathrm{NaY}$}

Stages of the process in the synthesis of zeolite $\mathrm{Y}$ include: preparation and aging of crystal seed Lynde Type $\mathrm{Y}$, preparation and aging starting materials, and hydrothermal synthesis.

\subsubsection{Seed}

Crystalline seed was prepared by adopting Lynde Type $\mathrm{Y}$ of Ginter et al (1992), by stirring the starting material consisting of: 2.72 grams of $\mathrm{Na}_{2} \mathrm{SiO}_{3}$ solution, 2.09 grams of $\mathrm{NaAlO} 2,4.07$ grams of $\mathrm{NaOH}$ and 19.95 grams of $\mathrm{H}_{2} \mathrm{O}$ at moderate speeds for 1 hour, and continued by aging at room temperature for 24 hours [9]

\subsubsection{Starting Material}

The starting material for the synthesis of Zeolite $Y$ from kaolin was prepared by adopting of Rahayu et.al. (2014) with modify by using micropore silica resulted in leaching metakaolin.

The molar ratio of silica / alumina in starting materials is adjusted for having to about $10 \mathrm{~mol} / \mathrm{mol}$, whereas the amount of silica is a combination of silica from silica-rich solids and from seed, as well as for the amount of alumina.

The content of silica-rich solids in a starting material solution is set in between $5-10 \%-w$. Fuhermore, the starting material was aged at room temperature for 11 hours and $\mathrm{pH} 13$ to produce gel form, before being processed hydrothermally.

\subsubsection{Synthesis of NaY Zeolite}

The Gel of starting material was synthesized hydrothermally in a stirred reactor made of teflon, which is equipped with reflux, at temperature between $91-93^{\circ} \mathrm{C}$ by using oil bath, to form zeolite Y. Sampling of synthesis product was started at $12 \mathrm{nd}$ hours and filtered and rinsed to $\mathrm{pH} 8$.

The synthesis product is dried in an oven with a temperature of $110 \mathrm{C}$ for 8 hours, prior to characterize of mineralalogi by XRD Rigaku Smartlab tool, morphology with SEM JEOL tool, and pore structure with NovaWin Quantachrome.

\subsection{Synthesis of ASA}

The synthesis of ASA was carried out by using a coprecipitation method with stages of a neutralization of alumina acid solution with an ammonia or sodium hydroxide solution, which it fed into reactor with flow in parallel for 1 hour at a temperature of $\pm 65^{\circ} \mathrm{C}$ to form the sol, followed by stabilization for 30 minutes before injection of sodium solution silicates, then done aging for 1-5 hours with $\mathrm{pH}$ 8-9 to form a gel that grows to form an amorphous phase.

The product was filtered and rinsed to a neutral $\mathrm{pH}$, dried in an oven with a temperature of $110 \mathrm{C}$ for 8 hours, and analyzed by a NovaWin Quantachrome for pore structure, mineralogy analysis with XRD Rigaku Smartlab tool, and morphology analysis with SEM JEOL tool

\section{Results and Discussion}

\subsection{Thermal Analysis}

Figure 1 show the result of thermal analysis of the kaolin Belitung. The DSC curve forms a downward peak at temperatures between $480^{\circ} \mathrm{C}-600^{\circ} \mathrm{C}$, where indicating the area of an endothermic reaction in which the kaolin is converted to metakoline.

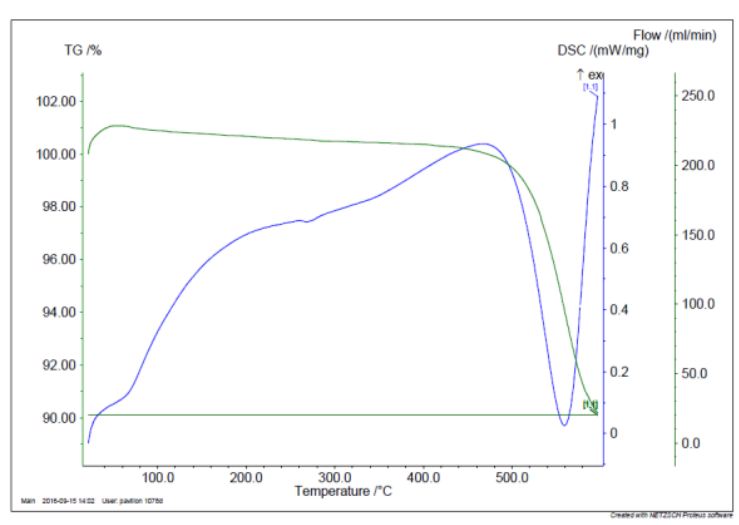

\section{FIG 1 DSC/TGA Curves of Kaolin Belitung}

Kaolin is converted to metakaolin through dehydroxylation process mechanism, which accompanied of release of water as in the equation of the reaction 3.1, and as shown in the TGA curve, Furthermore, a temperature of $700^{\circ} \mathrm{C}$ is set as calcining 
temperature of the kaolin Belitung to maximize releasing of bonded water in kaolin.

$$
\mathrm{Al}_{2} \mathrm{Si}_{2} \mathrm{O}_{5}(\mathrm{OH})_{4} \longrightarrow \mathrm{Al}_{2} \mathrm{Si}_{2} \mathrm{O}_{7}+2 \mathrm{H}_{2} \mathrm{O}
$$

\subsection{Dealumination Metakaolin By Leaching}

Table 1 shows that is important to determine the process conditions of leaching acurately, to obtain silica-rich solids having an appropriate $\mathrm{SiO}_{2} / \mathrm{Al}_{2} \mathrm{O}_{3}$ molar ratio for using as a raw material for the synthesis of zeolite $\mathrm{NaY}$.

Table 1. Influence of leaching condition to $\mathrm{SiO}_{2} / \mathrm{Al}_{2} \mathrm{O}_{3}$ ratio in silica-rich solid

\begin{tabular}{|c|c|c|}
\hline $\begin{array}{c}\text { Concentration } \\
\text { of } \mathrm{HCl} \\
(\mathrm{M})\end{array}$ & $\begin{array}{c}\text { Time of } \\
\text { Leaching } \\
\text { (Hours) }\end{array}$ & $\begin{array}{c}\text { Ratio of } \\
\mathrm{SiO}_{2} / \mathrm{Al}_{2} \mathrm{O}_{3} \\
(\mathrm{~mol} / \mathrm{mol})\end{array}$ \\
\hline \multirow{3}{*}{1} & 2 & 3,0 \\
& 3 & 2,9 \\
2 & 2 & 3,1 \\
\hline \multirow{2}{*}{2.5} & 3 & 5,8 \\
& 4 & 6,0 \\
& 4 & 6,2 \\
\hline 3 & 2 & 10,5 \\
& 3 & 23,9 \\
\hline & 4 & 24,5 \\
\hline
\end{tabular}

When leaching of metakaolin was carried out using $\mathrm{HCl} 2.5 \mathrm{M}$ at temperature of $100^{\circ} \mathrm{C}$ during 2 hours, a good results were obtained. That resulting in silica-rich solids having a suitable $\mathrm{SiO}_{2} / \mathrm{Al}_{2} \mathrm{O}_{3}$ molar ratio for $\mathrm{NaY}$ formation, ie between 7-10 mol / mol [1].

The concentration of $\mathrm{HCl}$ solution greatly influenced the molar ratio of silica / alumina in solid product, while the processing time did not have much effect. The alumina concentration in the solution of leaching product in between $25-28 \mathrm{~g} / \mathrm{L}$ was obtained by using $\mathrm{HCl} 2.5 \mathrm{M}$ at temperature of $100 \mathrm{C}$, which is used as an alumina source in ASA synthesis.

\subsection{Synthesis of NaY Zeolite from Kaolin}

\subsubsection{Diffractogram of Results of Synthesis $\mathrm{NaY}$ Zeolite From Kaolin}

Synthesis of $\mathrm{NaY}$ Zeolite were performed in a teflon stirred reactor equipped with a reflux, using a heating oil bath to achieve a reaction temperature in between $91-93^{\circ} \mathrm{C}, \mathrm{pH} \pm 13$, and starting material with a varied of $\mathrm{NaOH}, \quad \mathrm{SiO}_{2} / \mathrm{Al}_{2} \mathrm{O}_{3}$ and $\mathrm{H}_{2} \mathrm{O}$, where these materials were provided as a combined of rich-silica solids with seed. Table 2 and FIG. 2 - 5 show the results of NaY zeolite synthesis, using variations of the starting material formulations.
Table 2. Effect of Synthesis Process Conditions on Zeolite $\mathrm{NaY}$ Product

\begin{tabular}{|c|c|c|c|}
\hline \multicolumn{2}{|l|}{ Synthesis Process } & \multirow{2}{*}{$\begin{array}{c}\text { Zeolit NaY } \\
\text { Ratio of } \\
\mathrm{SiO}_{2} / \mathrm{Al}_{2} \mathrm{O}_{3} \\
(\mathrm{~mol} . \mathrm{mol})\end{array}$} & \multirow[b]{2}{*}{$\begin{array}{l}\text { Other } \\
\text { Zeolite }\end{array}$} \\
\hline $\begin{array}{l}\text { Starting Material } \\
(\mathrm{mol} / \mathrm{mol})\end{array}$ & $\begin{array}{c}\text { Time of } \\
\text { Syntesis } \\
\text { (hour) }\end{array}$ & & \\
\hline $1,5 \mathrm{Na}_{2} \mathrm{O}: \mathrm{Al}_{2} \mathrm{O}_{3}: 10,4 \mathrm{SiO}_{2}: 774 \mathrm{H}_{2} \mathrm{O}$ & 15 & 3,61 & $\mathrm{v}$ \\
\hline $2,6 \mathrm{Na}_{2} \mathrm{O}: \mathrm{Al}_{2} \mathrm{O}_{3}: 10,4 \mathrm{SiO}_{2}: 694 \mathrm{H}_{2} \mathrm{O}$ & $\begin{array}{l}12 \\
15 \\
18 \\
21\end{array}$ & $\begin{array}{l}3,43 \\
3,46 \\
3,70 \\
3,58\end{array}$ & $\begin{array}{l}\mathrm{V} \\
\mathrm{V} \\
\mathrm{V} \\
\mathrm{v}\end{array}$ \\
\hline $1,5 \mathrm{Na}_{2} \mathrm{O}: \mathrm{Al}_{2} \mathrm{O}_{3}: 9,9 \mathrm{SiO}_{2}: 375 \mathrm{H}_{2} \mathrm{O}$ & 15 & 3,08 & $\mathrm{~V}$ \\
\hline $2,5 \mathrm{Na}_{2} \mathrm{O}: \mathrm{Al}_{2} \mathrm{O}_{3}: 9,9 \mathrm{SiO}_{2}: 350 \mathrm{H}_{2} \mathrm{O}$ & 15 & 3,02 & - \\
\hline
\end{tabular}

Table 2 shows that the synthesis of zeolite Y from kaolin requires a high mineralizer solution with a molar ratio of $\mathrm{Na}_{2} \mathrm{O} / \mathrm{H}_{2} \mathrm{O}$ is not more than $140 \mathrm{~mol} / \mathrm{mol}$, and the starting material concentration has a molar ratio of $2.5 \mathrm{Na}_{2} \mathrm{O}: \mathrm{Al}_{2} \mathrm{O}_{3}: 9,9 \mathrm{SiO}_{2}: 350 \mathrm{H}_{2} \mathrm{O}$ suitable to produce zeolite $\mathrm{NaY}$. This starting material has the molar ratio of $\mathrm{SiO}_{2} / \mathrm{Al}_{2} \mathrm{O}_{3}$ as recommended by Murat 1992 of about $10 \mathrm{~mol} / \mathrm{mol}$, with high $\mathrm{SiO}_{2}$ and $\mathrm{Al}_{2} \mathrm{O}_{3}$ concentrations that will increase reaction velocity, also increase the greater Si-O and Al-O collision to build skeleton towards $\mathrm{NaY}$ zeolite formation. Synthesis time of 15 hours can prevent the occurrence of further reaction to form zeolite $P$.

FIG. 2 is a difractogram of the $\mathrm{NaY}$ synthesis produced by starting material with the formulation of Starting Material 1.5: $\mathrm{Na}_{2} \mathrm{O} \quad \mathrm{Al}_{2} \mathrm{O}_{3}: 10.41 \quad \mathrm{SiO}_{2}: 774$ $\mathrm{H}_{2} \mathrm{O}$, containing silica with $\mathrm{SiO}_{2} / \mathrm{Al}_{2} \mathrm{O}_{3}$ ratio of about $10 \mathrm{~mol} / \mathrm{mol}$, from leaching process in $\mathrm{HCl} 2.5 \mathrm{M}$ solution during 2 hours called silica-rich solids, and seeds.

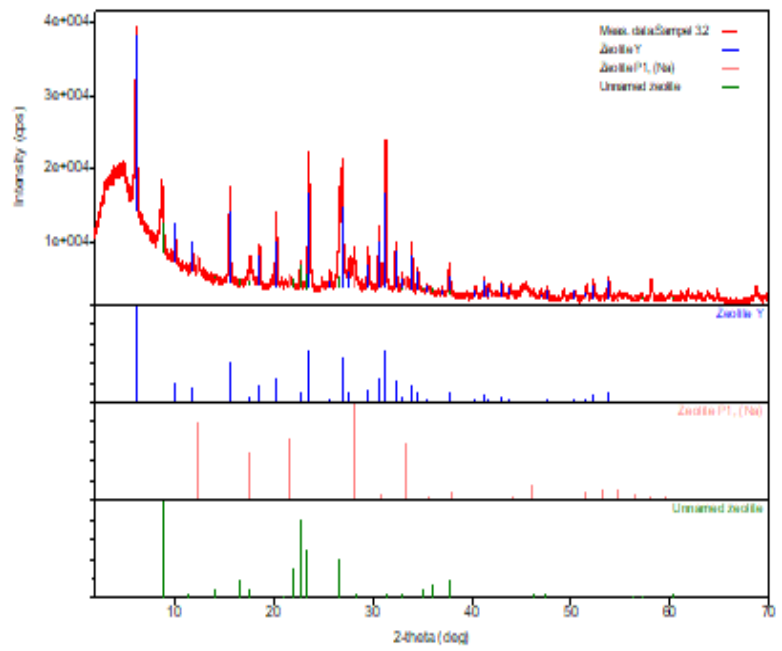

FIG. 2. Product of Zeolit NaY,15 Hours, $1.5 \mathrm{Na}_{2} \mathrm{O}: \mathrm{Al}_{2} \mathrm{O}_{3}: 10.41 \mathrm{SiO}_{2}: 774 \mathrm{H}_{2} \mathrm{O}$

How much silica-rich solids can be dissolved by the mineralizer under the conditions of the synthesis process, can be expected to be identical to how high 
purity zeolite $\mathrm{NaY}$ is in the crystals formed in the synthesis product.

The Diffractogram in FIG. 2 shows that the synthesis using a starting material formulation of $1.5 \mathrm{Na}_{2} \mathrm{O}: \mathrm{Al}_{2} \mathrm{O}_{3}: 10.41 \mathrm{SiO}_{2}: 774 \mathrm{H}_{2} \mathrm{O}$ produces a side reaction which forms zeolite $\mathrm{P}$ and another zeolite, which are probably. The results of parallel reaction. Increasing the quantity of $\mathrm{Na}_{2} \mathrm{O}$ and decreasing $\mathrm{H}_{2} \mathrm{O}$, as well as the extension of reaction time will be studied its effect on the ability of silica-rich solids mineralization in the reaction system by increasing $\mathrm{Na}_{2} \mathrm{O}$ in the starting material formulation $2.6 \mathrm{Na}_{2} \mathrm{O}$ : $\mathrm{Al}_{2} \mathrm{O}_{3}: 10.41 \mathrm{SiO}_{2}: 694 \mathrm{H}_{2} \mathrm{O}$, and the extension of reaction time. This formulation produces synthesis products with difractogranes as shown in FIG. 3.

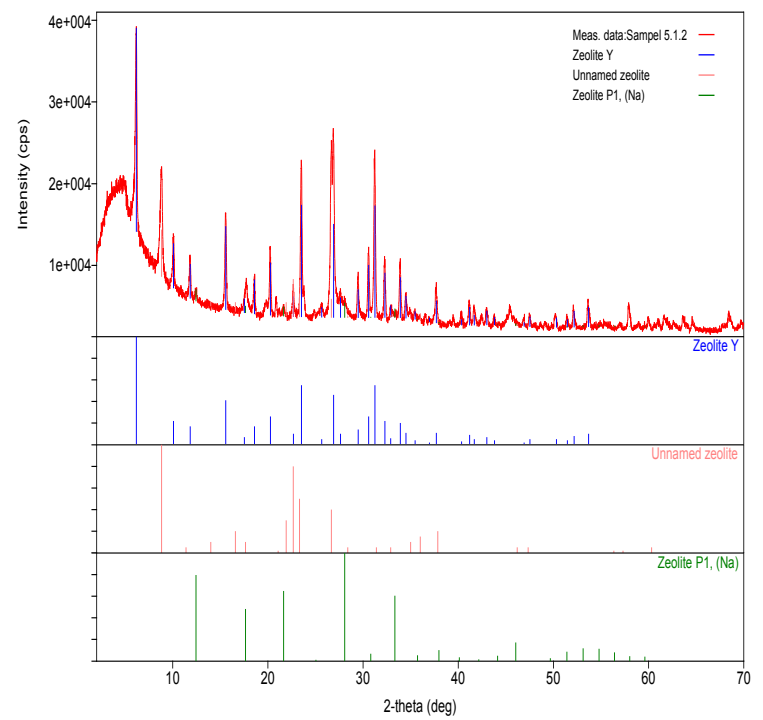

FIG. 3. Product of Zeolit $\mathrm{NaY}, 15$ Hours, 2. $6 \mathrm{Na}_{2} \mathrm{O}: \mathrm{Al}_{2} \mathrm{O}_{3}: 10.41 \mathrm{SiO}_{2}: 694 \mathrm{H}_{2} \mathrm{O}$

The result of synthesis Zeolit NaY using the starting material formulation

of

2.6 $6 \mathrm{Na}_{2} \mathrm{O}: \mathrm{Al}_{2} \mathrm{O}_{3}: 10.41 \mathrm{SiO}_{2}: 694 \mathrm{H}_{2} \mathrm{O}$ is presented in FIG.

3 , and showing a slightly higher the relative intensity in $\mathrm{NaY}$ zeolite. The addition of molar $\mathrm{Na}_{2} \mathrm{O}$ to the starting material, which does not increase the molar ratio of $\mathrm{Na}_{2} \mathrm{O} / \mathrm{H}_{2} \mathrm{O}$ significantly, so that it does not significantly affect the quality of the synthesis product significantly was observed. Accordingly, the concept of the collision frequency required to increase the reaction rate was involved in the design of this study, by increasing the $\mathrm{SiO}_{2}$ and $\mathrm{Al}_{2} \mathrm{O}_{3}$ concentrations, and the starting material formulation being 1.5 $\mathrm{Na}_{2} \mathrm{O}: \mathrm{Al}_{2} \mathrm{O}_{3}: 9.9 \mathrm{SiO}_{2}: 375 \mathrm{H}_{2} \mathrm{O}$ with higher of $\mathrm{SiO}_{2}$ and $\mathrm{Al}_{2} \mathrm{O}_{3}$ concentrations, but lower of $\mathrm{Na}_{2} \mathrm{O}$, and 2.6 $6 \mathrm{Na}_{2} \mathrm{O}: \mathrm{Al}_{2} \mathrm{O}_{3}: 9.9 \mathrm{SiO}_{2}: 350 \mathrm{H}_{2} \mathrm{O}$ with higher of $\mathrm{SiO}_{2}$ and $\mathrm{Al}_{2} \mathrm{O}_{3}$ concentrations,also higher of $\mathrm{Na}_{2} \mathrm{O}$, and giving diffractogram on FIG. 4 and FIG. 5 respectively.

Diffractogram of these synthesis result shown in FIG. 5 has a much higher NaY purity than in FIG. 4. This result proves that high concentrations in a reaction greatly affect the reaction rate, but there is a diffractogram of the synthesis shown in FIG. 5 having a much higher NaY purity than in Figure 4. These results prove that high concentrations in a reaction system are highly advantageous in terms of quantity and product quality, if the mineralizer is still capable of dissolving high solids.

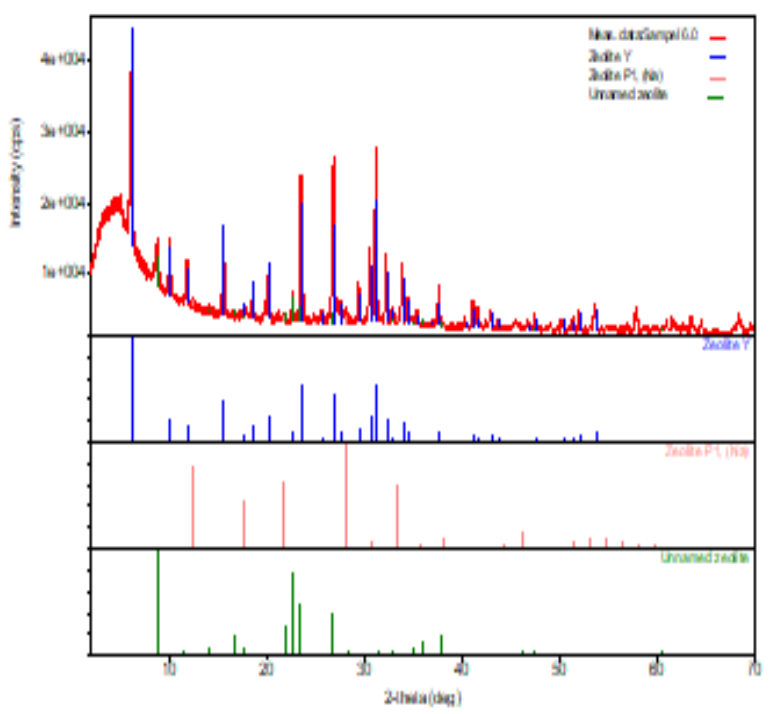

FIG. 4. Product of Zeolit NaY,15 Hours, $1.5 \mathrm{Na}_{2} \mathrm{O}: \mathrm{Al}_{2} \mathrm{O}_{3}: 9.9 \mathrm{SiO}_{2}: 375 \mathrm{H}_{2} \mathrm{O}$

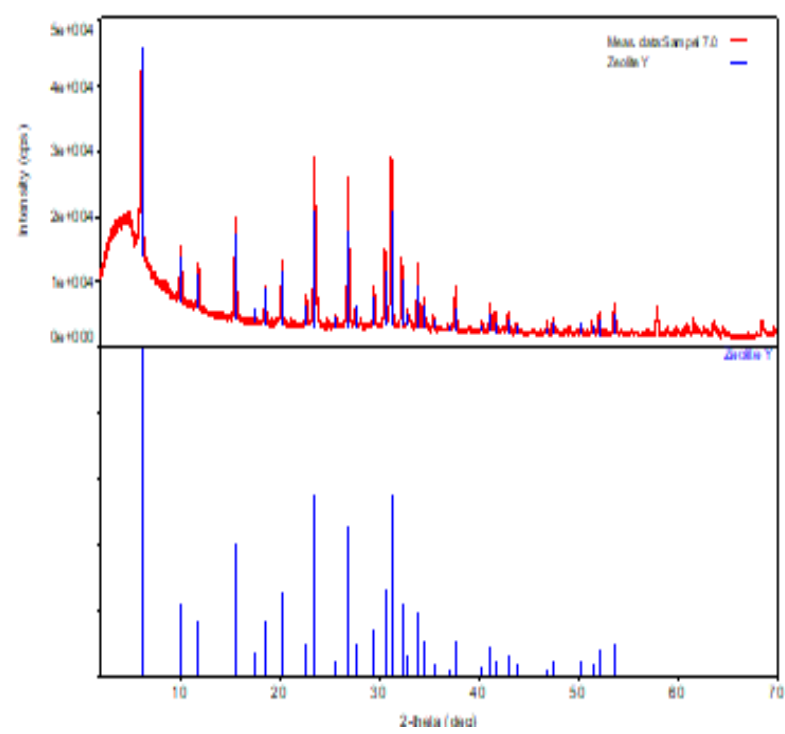

FIG. 5. Product of Zeolit NaY,15 Hours, 2. $6 \mathrm{Na}_{2} \mathrm{O}: \mathrm{Al}_{2} \mathrm{O}_{3}: 9.9 \mathrm{SiO}_{2}: 350 \mathrm{H}_{2} \mathrm{O}$

Diffractogram of the synthesis result shown in FIG. 5 has a much higher NaY purity than in FIG. 4. This result proves that high concentrations in a reaction greatly affect the reaction rate, but there is a diffractogram of the synthesis shown in FIG. 5 having a much higher NaY purity than in FIG. 4. These results prove that high concentrations in a reaction system are highly advantageous in terms of quantity and product quality, if the mineralizer is still capable of dissolving high solids.

This study was conducted by using the ratio of seed Lynde Type Y/silica rich solids $=0.5-1.0 \mathrm{w} / \mathrm{w}$. For comparison, the ratio of seed / active kaolin in Rahayu 
$(2014)=4.4 \mathrm{w} / \mathrm{w}$, while the ratio in Brown is $2.4 \mathrm{~b} /$ $w$ and $p H=14$, and yields 20\% -b NaY [7]; [10].

\subsubsection{Micrograph of Results of Synthesis $\mathrm{NaY}$ Zeolite From Kaolin}

The zeolite $\mathrm{NaY}$ with highest purity in the product was analyzed using SEM, JEOL JSM-6510A Analytical Scanning Electron Microscope, shown in FIG. 6 (a) and FIG. 6 (b) with successive magnification of 5000 and 10,000 times.

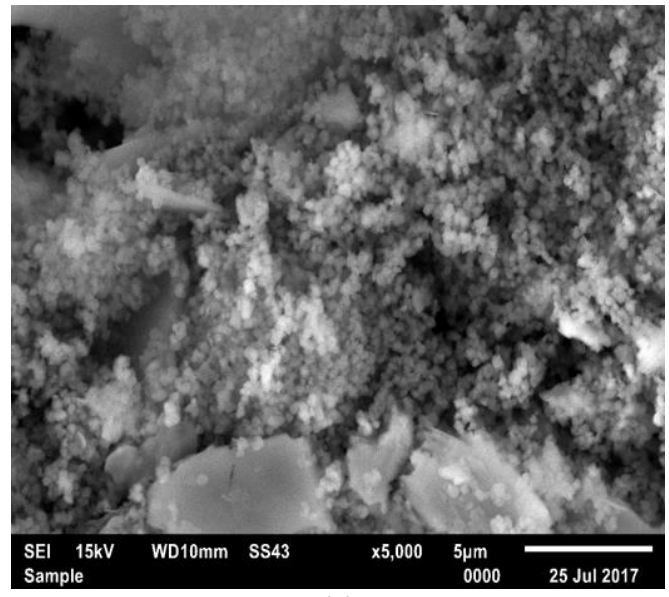

(a)

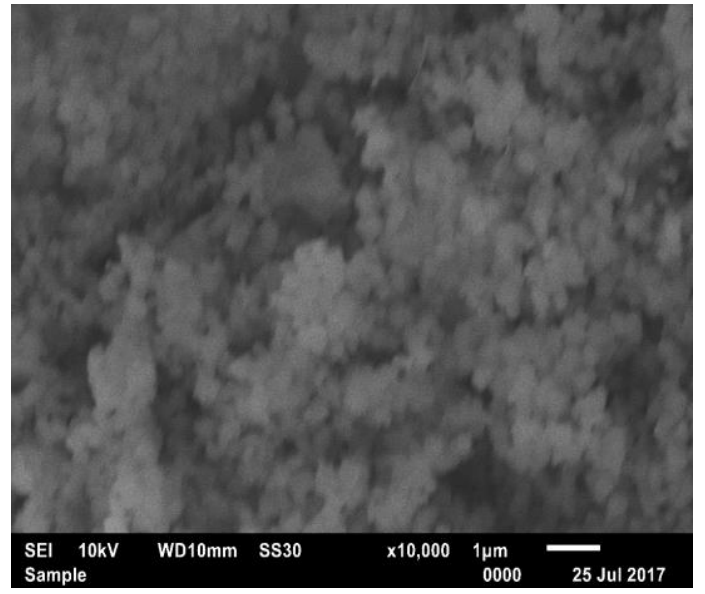

(b)

FIG. 6. Micrograph of Zeolit NaY,15 Hours, 2.6 $\mathrm{Na}_{2} \mathrm{O}: \mathrm{Al}_{2} \mathrm{O}_{3}: 9.9 \mathrm{SiO}_{2}: 350 \mathrm{H}_{2} \mathrm{O}$

(a) Mikrograph of $\mathrm{NaY}$ zeolite with magnification 5000 times

(b) Mikrograf of NaY zeolite with magnification 10,000 times

The microgaph shown in FIG 6 shows the mixture of the zeolite crystalline phase $\mathrm{Y}$ and the amorphous phase in the synthesis product. The white / gray crystal plates are zeolite Y crystals, while dark-colored clumps are amorphous.

In comparison to similar processes, the synthesis of zeolite Y from kaolin that Rahayu has done (2014) with a reaction time of 15 hours and the same process conditions, but using a mixture of 3 types of active kaolin: K700C, K1013C, K1050C, the composition is arranged to form a starting material formulation 6.4 $\mathrm{Na}_{2} \mathrm{O}: \mathrm{Al}_{2} \mathrm{O}_{3}: 10.4 \mathrm{SiO}_{2}: 932 \mathrm{H}_{2} \mathrm{O}$, the Zeolite $\mathrm{NaY}$ with molar ratio of $\mathrm{SiO}_{2} / \mathrm{Al}_{2} \mathrm{O}_{3}$ of $4.8 \mathrm{~mol} / \mathrm{mol}$ and the purity of zeolite Y $86 \%$ in crystals was obtained. While the crystalinity of product was $46 \%$ [7]

\subsection{Synthesis of ASA from Kaolin}

The synthesis of ASA using alumina from alumina-rich solution of leaching metakaolin was done by coprecipitation method, with process conditions at temperature of $60-65^{\circ} \mathrm{C}$ and $\mathrm{pH}$ in between $7-8$ at neutralizing stage to form sol and temperature of 50$55^{\circ} \mathrm{C}$ and $\mathrm{pH} 8-9$ at aging stage process to form gel. A $10 \%$ ammonia and $2 \mathrm{M} \mathrm{NaOH}$ are solution used for neutralizing acid in neutralization stage. The ASA synthesis results were analyzed their pore structure with the NovaWin Quantachrome tool, shown in Table 3, difractogram with XRD Rigaku Smartlab, shown in FIG.7, and the morphology with SEM, JEOL JSM6510A, shown in FIG 8.

Table 3. Effect of Process Conditions on Pore Structures

\begin{tabular}{|c|c|c|c|c|c|}
\hline \multicolumn{2}{|c|}{ Synthesis Process } & \multicolumn{3}{c|}{ Pore Structure of ASA } \\
\hline Neutralizer & $\begin{array}{c}\text { Rasio } \\
\mathrm{Si} / \mathrm{Al}, \\
(\mathrm{w} / \mathrm{w})\end{array}$ & $\begin{array}{c}\text { Aging } \\
\text { Time } \\
(\text { Hours })\end{array}$ & $\begin{array}{c}\text { Average } \\
\text { Pore } \\
\text { Diameter } \\
(\AA)\end{array}$ & $\begin{array}{c}\text { Specific } \\
\text { Surface } \\
\text { Area } \\
\left(\mathrm{m}^{2} / \mathrm{g}\right)\end{array}$ & $\begin{array}{c}\text { Pore } \\
\text { Volume } \\
(\mathrm{mL} / \mathrm{g})\end{array}$ \\
\hline $\mathrm{NH}_{4} \mathrm{OH}$ & 0,11 & 1 & 57,7 & 437 & 1,26 \\
& & 3 & 59,3 & 428 & 1,27 \\
& 0,22 & 1 & 62,5 & 439 & 1,37 \\
& 0,33 & 1 & 62,4 & 430 & 1.34 \\
& 0,11 & 1 & 52,6 & 372 & 0,98 \\
\hline $\mathrm{NaOH}$ & & & & & 432 \\
\end{tabular}

The results of the ASA synthesis shown in Table 3, appear to have a good pore structure, especially on high surface area and total pore volume, which will be used as a hydrocracking catalyst or matrix. But, average pore diameter slightly lower than desired (70 ̊̊).

Surprisingly, the addition of silica or an increase in $\mathrm{Si} / \mathrm{Al}$ ratio does not have a significant effect on the pore structure. As it is known that silica is required to provide acidic properties to ASA, via a silanol form attached to $\mathrm{Al}$ such as: [(H) O-Si-O-Al]. However, the addition of $\mathrm{Si}$ to the formation of ASA may destroy the pore structure, thus affecting mainly the pore specific surface area. In addition, the replacement of the Al atomic site by the $\mathrm{Si}$ atom can excessively remove the Bronsted acid-forming group ( $\mathrm{Si}-\mathrm{OH}-\mathrm{Al}$ ), which will decrease the Bronsted acid concentration (Chizallet, 2000).

Rahayu (2014) has also done the synthesis of ASA from kaolin by various procedures, but still has not achieved ASA with a high specific surface area and sufficient pore diameter. Furthermore, ASA was synthesized by using synthetic materials of aluminum sulphate $\left[\mathrm{Al}_{2}\left(\mathrm{SO}_{4}\right)_{3} \cdot \mathrm{xH}_{2} \mathrm{O}\right]$ and Sodium Aluminate $\left(\mathrm{NaAlO}_{2}\right)$. The best ASA with a specific surface area of 
$383.5 \mathrm{~m}^{2} / \mathrm{g}$, average pore diameter $=80.7 \AA$, and total pore volume $=0.78 \mathrm{ml} / \mathrm{g}$ was obtained.

The success of study of the ASA synthesis is also supported by ASA diffraction result, that similar to the commercial ASA as shown in Figure 7, and the ASA micrograph in Figure 8.

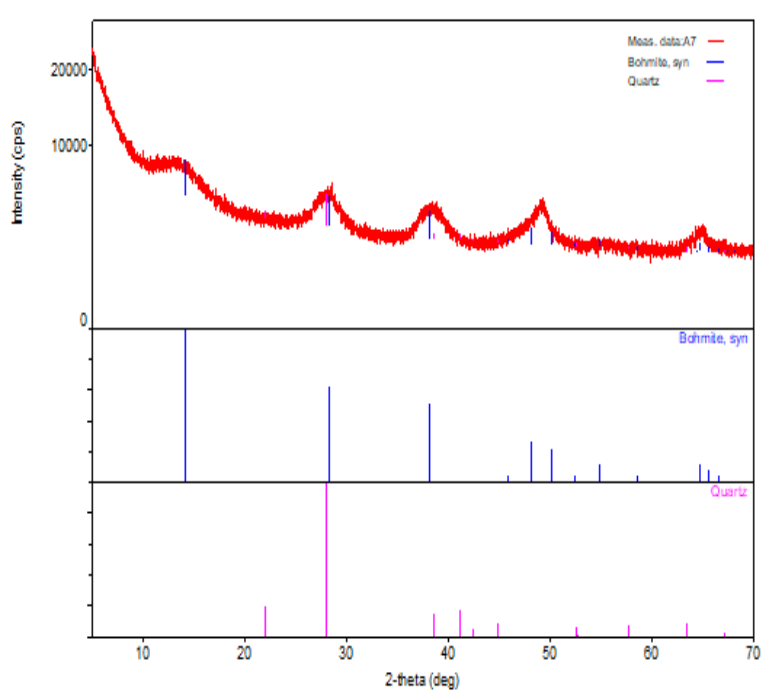

FIG.7. Diffractogram of ASA

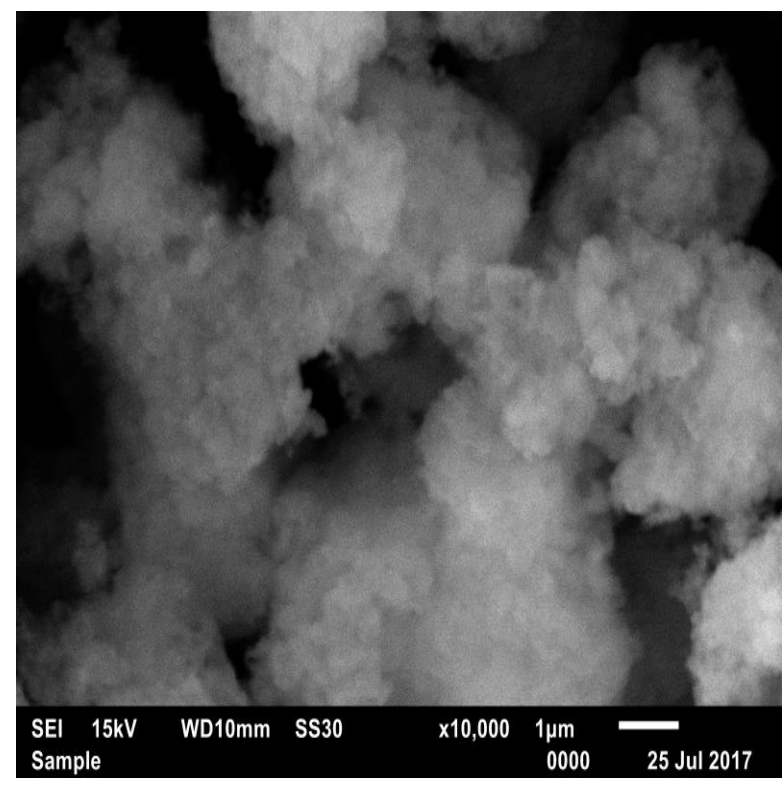

FIG. 8. Micrograph of ASA with magnification 10,000 times

\section{Conclusion}

Research on the synthesis of $\mathrm{NaY}$ and ASA zeolites from kaolin, using silica and alumina from the results of leaching metakaolin has been successfully performed, with high purity $\mathrm{NaY}$ zeolite, and ASA having high surface area, which is suitable for use as hydrocracking catalyst component. The silica and alumina were obtained by leaching in a solution $\mathrm{HCl}$
$2.5 \mathrm{M}$, at temperature of $100^{\circ} \mathrm{C}$ for 2 hour.. Overall, the process undertaken is more efficient and cheaper compared to what has been done before (Rahayu, 2014)

\section{Reference}

1. M. Murat, A. Amokrane, J. P. Bastide, L. Montanaro, Synthesis f Zeolits From Themally Activated Kaolinite. Some Observation On Nucleation and Growth, Clay Minerals, 27, 119130 (1992).

2. C. Belver, A.B.M. Miguel, A.V. Miguel, Chemical Activation of a Kaolinite under Acid and Alkaline Conditions. Spain (2002).

3. H. Hosono, Y. Mishima, H. Takezoe, K.J.D. MacKenzie, Nanomaterials: Research Towards Applications, Elsevier Ltd. The Boulevard, Langford Lane, Kidlington, Oxford OX5 IGB UK, (2006)

4. A.O.Ajayi, A.Y. Atta, B.O. Aderemi, and S.S. Adefila, Novel Method of Metakaolin Dealumination -Preliminary Investigation. Journal of Applied Sciences Research, 6(10): 1539-1546 (2010).

5. W.A., Mamani, G. Gustavo, H. Jonas and M. Johan and leached diatomaceous earth as raw materials for the synthesis of ZSM-5. Springer Plus, 3:292. (2014)

6. J.B. Adeoye, J.A. Omoleye. Development of Zeolit Y From Arobieye Mined Kaolin, 3rd International Conference on African Development Issues (CUICADI), 2016

7. E.S. Rahayu, Subagjo, T.W. Samadhi, M.G. Laniwati, Development of Hydrocracking Catalyst Support from Kaolin of Indonesian Origin, Advanced Materials Research, 896, 532-536, (2014)

8. Subagjo, E.S. Rahayu, T.W. Samadhi, M.L. Gunawan, Synthesis of NaY Zeolite Using Mixed Calcined Kaolin, [2016]

9. D.M. . Ginter, A. T. Bell, C.J. Radke,: Synthesis Of Microporous Materials, Molecular Sieves, Van Nostrand Reinhold, New York, 1, p 6, (1992)

10. S.M. Brown, dan G.M.Woltermann, "Zeolitized composite bodies and manufacture thereof' US Patent4235753 (1980).

11. C. Chizallet, and P. Raybaud, Chem. Phys. Chem. 11, 105. (2010)

\section{Acknowledgement}

Authors would like thanks to Directorate General of Research Reinforcement \& Development for funding this research through the National Competition Grants Program, 2016. 